\title{
Xylitol Production by Candida Species from Hydrolysates of Agricultural Residues and Grasses
}

\author{
Thomas P. West
}

\footnotetext{
check for updates

Citation: West, T.P. Xylitol Production by Candida Species from Hydrolysates of Agricultural Residues and Grasses. Fermentation 2021, 7, 243. https://doi.org/ $10.3390 /$ fermentation7040243
}

Academic Editor:

Emmanuel Atta-Obeng

Received: 20 September 2021

Accepted: 26 October 2021

Published: 28 October 2021

Publisher's Note: MDPI stays neutral with regard to jurisdictional claims in published maps and institutional affiliations.

Copyright: (C) 2021 by the author. Licensee MDPI, Basel, Switzerland. This article is an open access article distributed under the terms and conditions of the Creative Commons Attribution (CC BY) license (https:// creativecommons.org/licenses/by/ $4.0 /)$.
Department of Chemistry, Texas A\&M University, Commerce, TX 75429, USA; Thomas.West@tamuc.edu; Tel.: +01-903-886-5399

\begin{abstract}
Xylitol is an industrially important chemical due to its commercial applications. The use of xylitol as a sweetener as well as its utilization in biomedical applications has made it a high value specialty chemical. Although several species of yeast synthesize xylitol, this review focusses on the species of the genus Candida. The importance of the enzyme xylitol reductase present in Candida species as it relates to their ability to synthesize xylitol was examined. Another focus of this work was to review prior studies examining the ability of the Candida species to synthesize xylitol effectively from hydrolysates of agricultural residues and grasses. An advantage of utilizing such a hydrolysate as a substrate for yeast xylitol production would be decreasing the overall cost of synthesizing xylitol. The intent of this review was to learn if such hydrolysates could substitute for xylose as a substrate for the yeast when producing xylitol. In addition, a comparison of xylitol production by Candida species should indicate which hydrolysate of agricultural residues and grasses would be the best substrate for xylitol production. From studies analyzing previous hydrolysates of agricultural residues and grasses, it was concluded that a hydrolysate of sugarcane bagasse supported the highest level of xylitol by Candida species, although corncob hydrolysates also supported significant yeast xylitol production. It was also concluded that fewer studies examined yeast xylitol production on hydrolysates of grasses and that further research on grasses may provide hydrolysates with a higher xylose content, which could support greater yeast xylitol production.
\end{abstract}

Keywords: xylitol; agricultural residues; grasses; xylose reductase; Candida

\section{Introduction}

The industrially important specialty chemical xylitol, whose annual commercial production is now approaching 40,000 tons [1], has several commercial applications (Figure 1). The highest value commercial application for xylitol use is as an alternate sweetener in such products as chewing gum and various foods including ice cream and candy [2]. Beyond its utilization as a sweetener, biomedical applications exist for xylitol, including being used to prevent ear inflammations and its ability to stimulate murine hybridoma cell production [3-5]. Xylitol is also used as a sugar substitute for diabetics [5]. With respect to human health, it has been reported that xylitol promotes the growth of beneficial bacteria by promoting the synthesis of propionate and short-chain fatty acids in the human colon [6]. The chemical synthesis of xylitol from xylose still remains the dominant production method of xylitol production [5,7]. The industrial process to synthesize xylitol involves the chemical hydrolysis of xylan followed by the hydrogenation of the resultant hemicellulose hydrolysate by catalysts including palladium and nickel [5,7]. During the chemical synthesis of xylitol, both high temperatures and high pressure are usually required, with typical temperatures being 80-140 ${ }^{\circ} \mathrm{C}$ and 8-10 MPa hydrogen pressure being employed [5]. These processes are highly energy intensive, which makes the production costs of synthesizing xylitol very expensive considering the high temperature, pressure and metal catalyst used for a sustained period of time [5]. Another problem with the chemical production of xylitol is the synthesis of side products such as arabitol by the chemical catalyst, which 
necessitates the purification of the xylitol being produced [5]. Clearly, the cost of producing xylitol by a large-scale process is going to be high, which makes this possible production process not feasible economically in the long term [7-9]. A more realistic approach for large-scale xylitol production would be to use the pentose sugars present in hydrolysates of low-value plant biomass [10]. Low-value biomass residues are excellent candidates for the large-scale production of xylitol. Such low-cost residues are readily available as a raw material for xylitol synthesis compared to the process components used during the chemical bioconversion of xylose into xylitol. This could include utilizing hydrolysates of agricultural residues or hydrolysates derived from various species of grasses [11-16]. It has been well documented that a number of hydrolysates from agricultural residues contain a high level of pentoses that could be used for bioconversion into xylitol. Similarly, it has been shown that a variety of hydrolyzed grasses support biobased xylitol production. One advantage of grasses is that they generally require low fertilizer input while producing high yields. With the fiber content of the grasses being relatively high, it has been demonstrated that both physical and enzymatic treatments of the grasses can result in a hydrolysate containing a high xylose concentration.
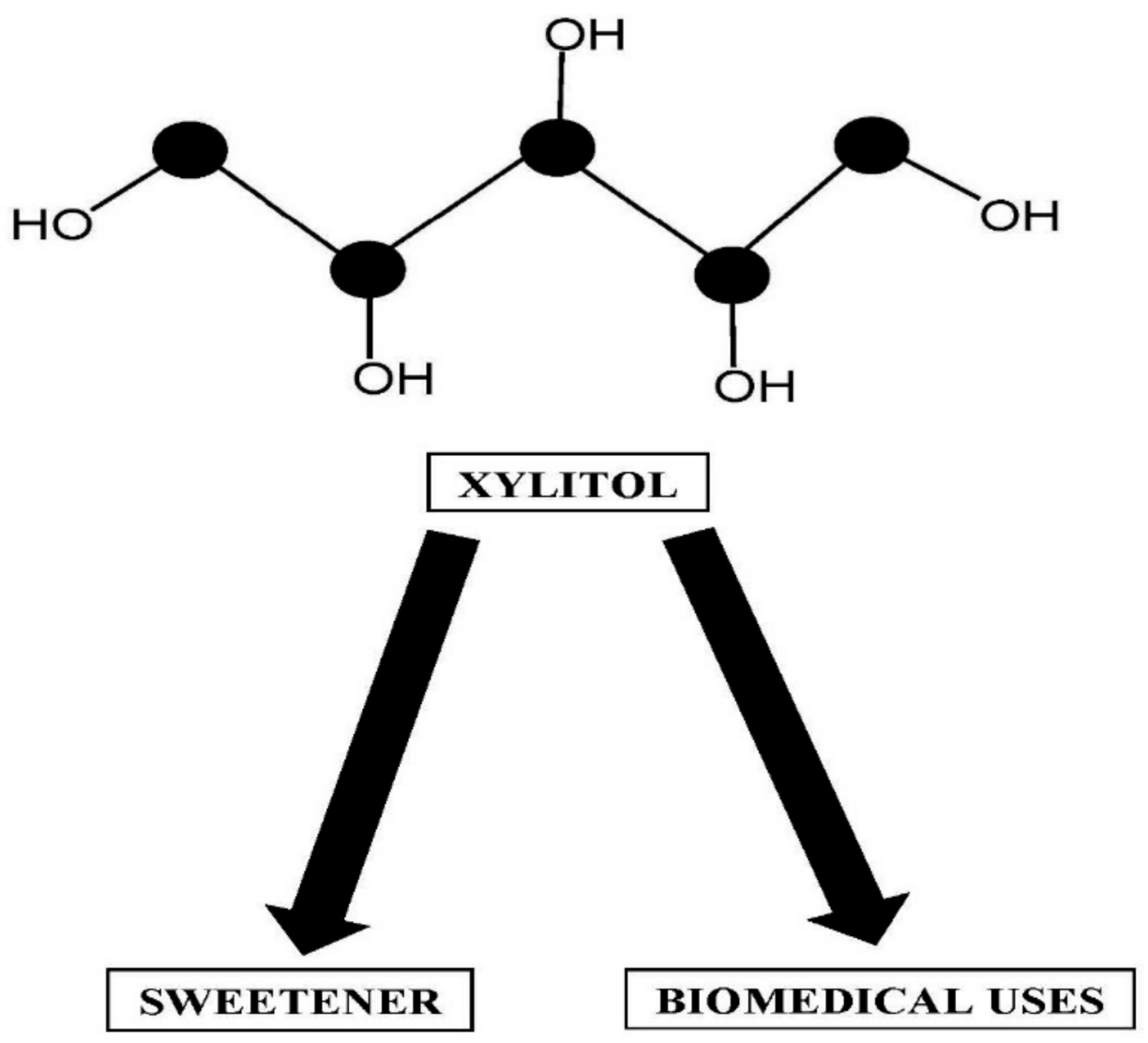

Figure 1. Structure of xylitol and its applications.

With hydrolysates containing high xylose levels, the bioconversion of the xylose present to xylitol can be accomplished by species of the yeast Candida. Prior work has identified a number of Candida species that are able to synthesize xylitol from the xylose present in hydrolyzed agricultural residues or grasses [17-21]. These yeast species contain the enzyme xylose reductase that primarily catalyzes the NADPH-dependent reduction of xylose to xylitol [1]. The resultant xylitol produced can be purified using activated carbon adsorption columns from the hydrolysate-containing medium [22].

In this review, xylitol production by species of the yeast Candida was examined relative to their ability to synthesize xylitol from hydrolysates of agricultural residues and from hydrolysates of grasses. The bioconversion of xylose to xylitol by Candida species 
from agricultural residue hydrolysates relative to grass hydrolysates was studied. The findings indicated which type of biomass has the greater potential for large-scale biobased xylitol synthesis.

\section{Pathway of Xylitol Biosynthesis in the Yeast Candida}

The ability of species of the yeast Candida to produce xylitol from xylose is due to the presence of the enzyme xylose reductase within their cells. Xylose reductase (EC 1.1.1.21) catalyzes the reduction of xylose by NADPH to the polyalcohol xylitol and NADP ${ }^{+}$ (Figure 2). It should be mentioned that some isolated yeast xylitol reductases can also use $\mathrm{NADH}$ as a cofactor. There is much interest in better understanding the xylose reductase structure to improve its efficiency in producing xylitol. Better understanding of yeast xylitol reductases could lead to the genetic engineering of this enzyme so that it has a greater affinity for its substrates, resulting in increased xylitol production. An engineered high activity xylitol reductase could efficiently synthesize xylitol from the high xylosecontaining agricultural residues and grasses on an industrial scale. Xylose reductase has been investigated in a number of Candida species including Candida tenuis, Candida guillermondii, Candida parapsilosis, Candida intermedia and Candida tropicalis [23-32].

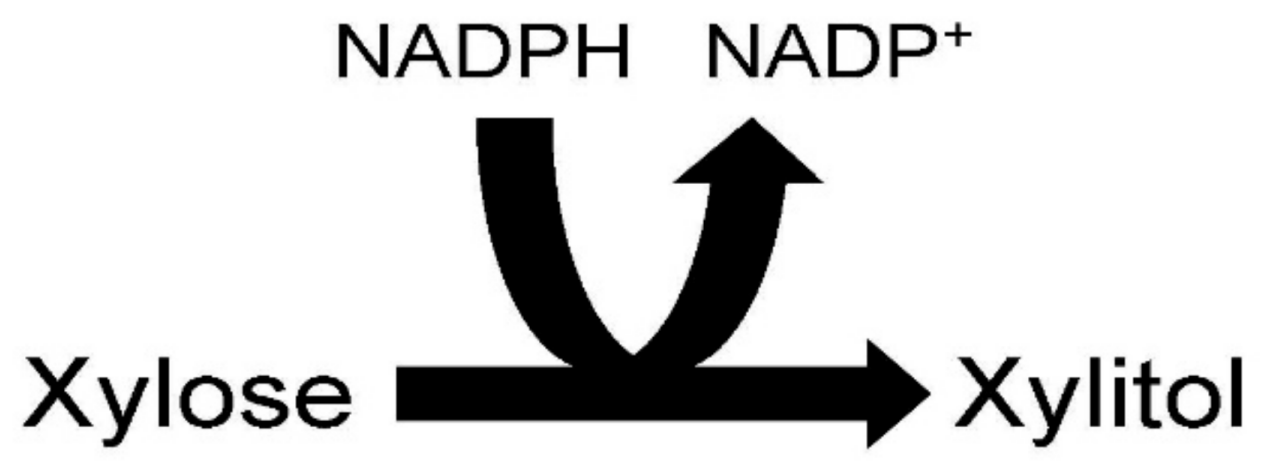

Figure 2. Xylose reductase reaction.

The xylose reductase from $C$. tenuis has been purified by dye ligand affinity chromatography and ion exchange chromatography to homogeneity [23]. Structurally, the purified enzyme was found to be a monomer or homodimer with each subunit having a molecular weight of 36,000-43,000 daltons [23,26]. This reductase from $C$. tenuis appears to differ from other family members of the aldo-keto reductase group, which exist purely as monomers. The isoelectric point of the reductase was determined to be 4.7 [23]. The reductase prefers NADPH compared to NADH as a cofactor based on binding specificity and it has been shown that $\mathrm{NADP}^{+}$is a strong competitive inhibitor of the reaction [23]. The reductase was shown to contain a catalytic tetrad consisting of tyrosine, lysine, aspartic acid and histidine residues essential to its activity [26]. The lysine residue has been shown to be located near the coenzyme-binding site. Further, the presence of the epsilon amino group of the lysine residue in the reductase is thought to be a key element in its mode of catalysis [26]. In a pH 7.0-buffered assay incubated at $25^{\circ} \mathrm{C}$, the C. tenuis reductase had a $\mathrm{K}_{\mathrm{m}}$ and $\mathrm{k}_{\text {cat }}$ of $87 \mathrm{mM}$ and 18.2/s, respectively, for xylose. The reductase had a $\mathrm{K}_{\mathrm{m}}$ of $4.8 \mu \mathrm{M}$ and $21.9 / \mathrm{s}$, respectively, for NADPH, while it had a $\mathrm{K}_{\mathrm{m}}$ of $25.4 \mu \mathrm{M}$ and $\mathrm{k}_{\text {cat }}$ of $18.1 / \mathrm{s}$, respectively, for NADH [23].

The xylose reductase gene fragment isolated from C. guilliermondii ATCC 20118 was cloned into Pichia pastoris GS115 [24]. This resulted in two xylose reductase activities being synthesized [24]. The xylose reductase activity, secreted extracellularly, was found to utilize only NADPH as its cofactor [24]. The molecular weight of this xylose reductase was shown to be 36,000 daltons [24]. The reductase was composed of 317 amino acids with the pI of the reductase shown to be 5.7 [24]. It was noted that the reductase was highly hydrophobic relative to amino acid composition including many leucine residues. It was also shown 
that three cysteine residues and seven histidine residues were present within the reductase structure similar to the P. pastoris xylose reductase [24]. In C. guilliermondii FTI 20037, a prior report characterized xylitol reductase in a crude extract prepared from cells cultured in a medium containing sugarcane bagasse hydrolysate [25]. The kinetics of the crude reductase were analyzed and it was observed that the xylose reductase had a $\mathrm{K}_{\mathrm{m}}$ of $64 \mathrm{mM}$ for xylose and a $\mathrm{K}_{\mathrm{m}}$ of $9.5 \mu \mathrm{M}$ for $\mathrm{NADPH}$ [25]. The optimal $\mathrm{pH}$ for the reductase was 5.5 and the enzyme was most stable when buffered at a $\mathrm{pH}$ between 5.0 and 5.5 [25]. The optimal temperature for the reductase was $65^{\circ} \mathrm{C}$ and its enzyme activity was still stable after being heated to $60{ }^{\circ} \mathrm{C}$ for $10 \mathrm{~min}$ [25].

In C. intermedia, it was noted that the yeast contained two different forms of xylose reductase [27]. The isoforms of the enzyme were purified to homogeneity by a combination of affinity chromatography and ion exchange chromatography with relatively high yields. One form of the reductase was strictly specific for NADPH as a cofactor with $a K_{m}$ of $61 \mu \mathrm{M}$ and a $\mathrm{k}_{\text {cat }}$ of $14.6 / \mathrm{s}$, while its $\mathrm{K}_{\mathrm{m}}$ and $\mathrm{k}_{\text {cat }}$ for xylose were $82 \mathrm{mM}$ and 14.6/s, respectively. The second form of the reductase was able to utilize either NADPH or NADH as a cofactor [27]. The $\mathrm{K}_{\mathrm{m}}$ of this reductase isoform for NADPH was $56 \mu \mathrm{M}$ and its $\mathrm{k}_{\text {cat }}$ was $11 / \mathrm{s}$, while its $\mathrm{K}_{\mathrm{m}}$ for $\mathrm{NADH}$ was $28 \mu \mathrm{M}$ and its $\mathrm{k}_{\text {cat }}$ was $11.2 / \mathrm{s}$. The $\mathrm{K}_{\mathrm{m}}$ of this reductase for xylose was about $50 \mathrm{mM}$ and its $\mathrm{k}_{\text {cat }}$ was about 10/s [27]. Structurally, both isoforms exist as homodimers with individual subunits having a molecular weight of 36,000 daltons. The isoelectric point of each isoform was found to differ with the NADPHspecific isoform having a $\mathrm{pI}$ of 4.38 , while the second form had a pI of 4.59 [27]. It is interesting to note that the number of titratable cysteines in each isoform also differed. The NADPH-specific isoform had five titratable cysteines, while the second form had only two [27]. The inactivation of the cysteines in the NADPH-specific isoform resulted in a total loss of its activity [27]. It was thought that the ratio of available NADPH to NADH was a determining factor as to which isoform of the reductase was most active in the C. intermedia cells [27].

The xylitol reductase gene in C. parapsilosis was cloned in Escherichia coli and the reductase was purified to homogeneity using ion exchange chromatography, affinity chromatography and preparative electrophoresis [28]. The molecular weight of the C. parapsilosis reductase was 36,629 daltons and was composed of 324 amino acids. The reductase was shown to have a high catalytic efficiency for xylose as a substrate. The $\mathrm{K}_{\mathrm{m}}$ for xylose was calculated to be $31.5 \mathrm{mM}$, with its $\mathrm{k}_{\text {cat }}$ being $46 / \mathrm{s}$. Interestingly, this reductase preferred $\mathrm{NADH}$ as its cofactor instead of NADPH [28]. The $\mathrm{K}_{\mathrm{m}}$ of the reductase for NADH was $3.1 \mu \mathrm{M}$ compared to the $\mathrm{K}_{\mathrm{m}}$ for NADPH being $36.5 \mu \mathrm{M}$ [28]. The $\mathrm{k}_{\mathrm{cat}}$ of the reductase for $\mathrm{NADH}$ was 45.9 /s relative to the $\mathrm{k}_{\text {cat }}$ for NADPH being 4.6/s [28]. The optimal $\mathrm{pH}$ for the reductase was 6.0 , while its temperature stability was greatest if stored at $4{ }^{\circ} \mathrm{C}$. The reductase was subject to non-competitive inhibition by its product xylitol. The reaction mechanism for the $C$. parapsilosis reductase was thought to be an ordered sequential bi bi mechanism as has been proposed for other xylitol reductases [28].

In C. tropicalis, the properties of xylose reductase have been investigated [30-32]. The xylose reductase from $C$. tropicalis has been purified by cloning the xylitol reductase gene into Escherichia coli [30]. The purified reductase was crystalized and analyzed using X-ray diffraction [30]. The properties of a crude xylitol reductase activity isolated from a strain of C. tropicalis adapted to a hydrolysate of tree sawdust were studied [31]. The reductase was shown to be specific for $\mathrm{NADP}^{+}$as its cofactor [31]. The reductase was still $95 \%$ active following 120 days at $-80{ }^{\circ} \mathrm{C}$. Further, the reductase was observed to be stable at a $\mathrm{pH}$ range between $\mathrm{pH} 5$ and 7 . The crude enzyme was stable for $24 \mathrm{~h}$ when incubated between 25 and $40{ }^{\circ} \mathrm{C}$. The $\mathrm{K}_{\mathrm{m}}$ of the reductase was calculated to be $81.78 \mathrm{mM}$ for xylose and $7.29 \mu \mathrm{M}$ for NADPH [31]. The $V_{\max }$ of the enzyme for xylose and NADPH was $178.57 \mu \mathrm{M} / \mathrm{min}$ and $12.5 \mu \mathrm{M} / \mathrm{min}$, respectively [31]. The $\mathrm{K}_{\mathrm{m}}$ and $\mathrm{V}_{\max }$ values for the reductase were thought to be associated with the high rate of xylitol production noted by the strain. The molecular weight of the reductase was 36,600 daltons [30]. Another study using recombinant versions of the C. tropicalis reductase found that a serine residue at position 279 of its structure 
allowed increased catalysis compared to the presence of a leucine or an asparagine residue at position 279 [32]. The importance of a serine residue at position 279 of the reductase was thought to involve the binding of NADPH [32].

In summary, when comparing the previously investigated xylose reductases isolated from various species of Candida, there appear to be some similarities. First, the xylose reductases isolated from species of Candida appear to exhibit similar molecular weights. In general, the $\mathrm{pH}$ optimum of many of the characterized reductases from Candida species was similar. In addition, some of the reductases synthesized by the Candida species had a strict cofactor requirement for NADPH, while some synthesized a reductase activity that preferred NADPH as a cofactor but could still use NADH as a cofactor to catalyze the reaction. With respect to the kinetic properties of the Candida xylose reductases, the affinity of the enzymes for the nicotinamide cofactor was usually much greater than their affinity for xylose as a substrate.

\section{Xylitol Production by Candida Species from Agricultural Residues}

Several agricultural residue hydrolysates have been tested for their ability to support xylitol production by species of Candida (Table 1). The amount of xylose present in the hydrolyzed residues depends on the level of hemicellulose present in the agricultural residue being tested, and thus varies with the type of agricultural residue.

As can be seen in Table 1, the length of time used by the Candida species at specific temperatures to ferment the agricultural residue and the type of agricultural residue utilized greatly influenced the fermentation parameters xylitol concentration and yield. The yeast C. guilliermondii was shown to synthesize xylitol from the xylose produced from a $10 \%$ sulfuric acid hydrolysate of apple pomace containing about $33 \%$ cellulose and $24 \%$ hemicellulose [33]. Detoxified, $2.5 \%$ sulfuric acid hydrolysates $\left(121{ }^{\circ} \mathrm{C}, 30 \mathrm{~min}\right)$ of banana (29.4\% cellulose, 32.6\% hemicellulose and $15.4 \%$ lignin) and water hyacinth ( $24.9 \%$ cellulose, $45.1 \%$ hemicellulose and 5.1\% lignin) leaves supported xylitol production by $C$. tropicalis cells with the cells synthesizing higher xylitol concentrations on banana leaves than water hyacinth [34]. Detoxified, $1.25 \%$ sulfuric acid hydrolysates $\left(125{ }^{\circ} \mathrm{C}\right.$, $30 \mathrm{~min}$ ) of chestnut shells ( $35.9 \%$ cellulose, $20 \%$ hemicellulose and $42.6 \%$ lignin) supported lower xylitol levels and yields by $C$. tropicalis cells over a longer fermentation period than observed when the yeast cells were grown on dilute acid hydrolysates of banana and water hyacinth leaves [35]. Xylitol production by Candida boidinii on cocoa pod husk (30.8\% cellulose, $21.2 \%$ hemicellulose and $25.6 \%$ lignin) acid hydrolysate $\left(120{ }^{\circ} \mathrm{C}\right)$ was observed, although an extensive length of fermentation time was required [36]. A number of investigations have explored the use of corncob (35\% cellulose, $25 \%$ hemicellulose and $23 \%$ lignin) hydrolysates to support xylitol production by a variety of C. tropicalis strains [37-43]. The conditions that supported the highest xylitol production and yield were observed when C. tropicalis NCIM 3123 cells were immobilized in calcium alginate beads and non-detoxified corncob hemicellulosic hydrolysate was cycled through the beads for $72 \mathrm{~h}$ at $30^{\circ} \mathrm{C}$ [43]. In another two studies [40,41], xylitol synthesis by C. tropicalis MTCC 6192 on detoxified, acid-treated, corncob hydrolysates was explored. It was noted that the $0.5 \%$ nitric acid-treated corncob hydrolysate $\left(121^{\circ} \mathrm{C}, 30 \mathrm{~min}\right)$ detoxified by activated charcoal and ion exchange resulted in a high xylitol concentration and yield being produced by ATCC 6192 after $48 \mathrm{~h}$ at $30{ }^{\circ} \mathrm{C}$ [41]. A non-detoxified, $1 \%$ sulfuric acid corncob hydrolysate $\left(125^{\circ} \mathrm{C}, 1 \mathrm{~h}\right)$ supported xylitol production by C. tropicalis CCTCC M2012462 at a relatively high yield after $84 \mathrm{~h}$ at $35{ }^{\circ} \mathrm{C}$ [38]. A genetically engineered strain C. tropicalis PNL3, which contained xylanase and xylosidase activities, was examined for its ability to utilize $15-20 \%$ sulfuric acid-treated corncob hydrolysate $\left(160-180{ }^{\circ} \mathrm{C}, 15-20 \mathrm{~min}\right)$ and was found to produce xylitol at a $61 \%$ yield after $24 \mathrm{~h}$ at $35{ }^{\circ} \mathrm{C}$ [39]. A $6 \%$ sulfuric acid-treated cotton stalk hydrolysate $\left(140^{\circ} \mathrm{C}, 15 \mathrm{~min}\right)$ was shown to support a low level of xylitol when subjected to C. tropicalis KUEN 1022 fermentation for $96 \mathrm{~h}$ at $30{ }^{\circ} \mathrm{C}$ [44]. Similarly, a $2 \%$ sulfuric acid-treated hydrolysate $\left(170{ }^{\circ} \mathrm{C}\right)$ of olive pomace $(10.4 \%$ cellulose, $11.5 \%$ hemicellulose and $23.7 \%$ lignin) or a dilute hydrochloric acid-treated $\left(90{ }^{\circ} \mathrm{C}, 3 \mathrm{~h}\right)$ olive 
pruning ( $16.5 \%$ cellulose, $20.8 \%$ hemicellulose and $21.3 \%$ lignin) hydrolysate produced a low xylitol yield by C. boidinii and C. tropicalis, respectively, after $96 \mathrm{~h}$ at $30{ }^{\circ} \mathrm{C}$ [45,46]. A $2 \%$ sulfuric acid hydrolysate $\left(130{ }^{\circ} \mathrm{C}, 1 \mathrm{~h}\right)$ of rapeseed straw $(31.5 \%$ cellulose, $17.4 \%$ hemicellulose and $17.8 \%$ lignin) was tested under non-detoxified conditions for its ability to support xylitol production by C. guilliermondii ATCC 201935 and was noted to support the synthesis of a low xylitol concentration and yield after $144 \mathrm{~h}$ at $30{ }^{\circ} \mathrm{C}$ [47]. Xylitol synthesis by C. guilliermondii ATCC 201935 grown on the rapeseed straw hydrolysate was shown to produce a slightly higher xylitol level than that observed compared to the xylitol level produced by the same C. guilliermondii strain grown on the hydrolysate from apple pomace $[33,47]$. Two studies analyzed rice straw $(25 \%$ cellulose, $18 \%$ hemicellulose and $21.6 \%$ lignin) hydrolysates as substrates for xylitol production by $C$. tropicalis $[48,49]$. Both studies involved dilute sulfuric acid treatments of rice straw. In these investigations, the C. tropicalis strains produced similar xylitol levels and yields on the pretreated rice straw independent of fermentation time at pretreatment process at $30^{\circ} \mathrm{C}[48,49]$. A dilute sulfuric acid-treated sisal fiber ( $48.2 \%$ cellulose, $31.8 \%$ hemicellulose and $11.1 \%$ lignin) hydrolysate supported a low xylitol yield by C. tropicalis CCT 1516 after $60 \mathrm{~h}$ at $30^{\circ} \mathrm{C}$ compared to the majority of agricultural residues (Table 1) tested [50]. Several studies [51-57] have explored using different Candida species to synthesize xylitol from hydrolysates of sugar cane bagasse, which is composed of about $40 \%$ cellulose, $26 \%$ hemicellulose and $26 \%$ lignin (Table 1). Of the species examined, it was found that $C$. tropicalis was capable of producing much higher xylitol concentrations and yields than the xylitol concentrations and yields observed for C. guilliermondii or C. magnoliae grown on the hydrolysates (Table 1). It was also observed that xylitol production and yield by $C$. guilliermondii were much higher after a shorter fermentation period on the $10 \%$ sulfuric acid-treated sugarcane bagasse hydrolysate $\left(121{ }^{\circ} \mathrm{C}, 10 \mathrm{~min}\right)$ than noted for the $1.5 \%$ sulfuric acid-treated hydrolysate $\left(105^{\circ} \mathrm{C}, 1 \mathrm{~h}\right)$ of Candida magnolia [51,52]. There was a range of xylitol concentrations and yields produced by the strains of $C$. tropicalis when grown on acid hydrolysates of sugarcane bagasse that was dependent on the strain chosen. The highest xylitol level and yield were produced by the newly identified C. tropicalis JA2 after being grown for $39 \mathrm{~h}$ on the steam-exploded and $0.5 \%$ sulfuric acid-treated hydrolysate [55]. Compared to the acid-hydrolyzed sugarcane bagasse hydrolysate, sugarcane straw ( $31.7 \%$ cellulose, $27 \%$ hemicellulose and $31.1 \%$ lignin) hydrolysate supported lower xylitol production by C. guilliermondii ATCC 201935 but did exhibit a higher xylitol yield on the sugarcane straw hydrolysate [51,57]. Several studies have examined the immobilization of $C$. tropicalis and C. guilliermondii cells for xylitol production from sugarcane bagasse hydrolysates using various adsorbents [22,58-60]. The adsorbents used in these studies included cell entrapment in calcium alginate beads as well as treatment with polyethyleneimine or epichlorohydrin [58-60]. The purification of xylitol from agricultural residues involves such processes as concentration and crystallization [22] A procedure to improve the clarity of the xylitol produced from agricultural residues has been developed, where a fixed-bed adsorption column of activated carbon was used to obtain xylitol with the degree of purity necessary for commercialization [22]. The xylitol yields resulting from the bioconversion by the immobilized yeast cells of the sugarcane biomass hydrolysates varied from 0.59 to $0.74 \mathrm{~g} / \mathrm{g}$ [22,58-60]. Lastly, a $1.5 \%$ sulfuric acidtreated hydrolysate $\left(121^{\circ} \mathrm{C}, 30 \mathrm{~min}\right)$ of wheat bran $(26.6 \%$ cellulose, $16.8 \%$ hemicellulose and $6.4 \%$ lignin) supported significant xylitol production by C. boidinii at a high yield after only $24 \mathrm{~h} \mathrm{[61].} \mathrm{It} \mathrm{can} \mathrm{be} \mathrm{summarized} \mathrm{from} \mathrm{the} \mathrm{previous} \mathrm{studies} \mathrm{investigating} \mathrm{xylitol}$ production and yields on agricultural residues that a hydrolysate of sugarcane bagasse supported the highest level of yeast xylitol production. It should be mentioned that corncob hydrolysates more consistently supported high xylitol production than sugarcane bagasse hydrolysates independent of the Candida strain chosen (Table 1). 
Table 1. Xylitol production by Candida species strains grown on hydrolysates of agricultural residues.

\begin{tabular}{|c|c|c|c|c|c|}
\hline $\begin{array}{l}\text { Agricultural } \\
\text { Residue }\end{array}$ & $\begin{array}{c}\text { Candida Species/ } \\
\text { Strain }\end{array}$ & $\begin{array}{l}\text { Growth } \\
\text { Conditions }\end{array}$ & $\begin{array}{c}\text { Xylitol } \\
{\text { Level }(\mathrm{g} / \mathrm{L})^{1}}^{1}\end{array}$ & Yield $(g / g)^{1}$ & Reference \\
\hline Apple pomace & C. guilliermondii ATCC 201935 & $96 \mathrm{~h}, 30^{\circ} \mathrm{C}$ & 9.4 & 0.38 & {$[33]$} \\
\hline Banana leaves & C. tropicalis MTCC 230 & $48 \mathrm{~h}, 30{ }^{\circ} \mathrm{C}$ & 12.4 & 0.47 & [34] \\
\hline Chestnut shells & C. tropicalis M43 & $120 \mathrm{~h}, 30^{\circ} \mathrm{C}$ & 6.3 & 0.19 & {$[35]$} \\
\hline Cocoa pod husks & C. boidinii XM02G & $372 \mathrm{~h}, 30^{\circ} \mathrm{C}$ & 11.3 & 0.52 & [36] \\
\hline Corncob & C. tropicalis CCTCC M2012462 & $84 \mathrm{~h}, 35^{\circ} \mathrm{C}$ & 38.8 & 0.70 & [38] \\
\hline Corncob & C. tropicalis MTCC 6192 & $90 \mathrm{~h}, 30^{\circ} \mathrm{C}$ & 29.6 & 0.60 & [39] \\
\hline Corncob & C. tropicalis MTCC 6192 & $48 \mathrm{~h}, 30^{\circ} \mathrm{C}$ & 40.0 & 0.62 & [40] \\
\hline Corncob & C. tropicalis PNL3 & $24 \mathrm{~h}, 35^{\circ} \mathrm{C}$ & 30.5 & 0.61 & [41] \\
\hline Corncob & C. tropicalis NCIM 3123 & $72 \mathrm{~h}, 30^{\circ} \mathrm{C}$ & 41.0 & 0.73 & [43] \\
\hline Cotton stalk & C. tropicalis KUEN 1022 & $96 \mathrm{~h}, 30^{\circ} \mathrm{C}$ & 3.5 & 0.36 & [44] \\
\hline Olive pomace & C. boidinii NCAIM Y.01308 & $96 \mathrm{~h}, 30^{\circ} \mathrm{C}$ & 6.0 & 0.43 & [45] \\
\hline Olive pruning & C. tropicalis NBRC 0618 & $96 \mathrm{~h}, 30^{\circ} \mathrm{C}$ & ND & 0.23 & [46] \\
\hline Rapeseed straw & C. guilliermondii ATCC 201935 & $144 \mathrm{~h}, 30^{\circ} \mathrm{C}$ & 14.4 & 0.42 & [47] \\
\hline Rice straw & C. tropicalis MTCC 6192 & $96 \mathrm{~h}, 30^{\circ} \mathrm{C}$ & 25.8 & 0.60 & [48] \\
\hline Rice straw & C. tropicalis ATCC 9968 & $50 \mathrm{~h}, 30^{\circ} \mathrm{C}$ & 26.5 & 0.58 & [49] \\
\hline Sisal fiber & C. tropicalis CCT 1516 & $60 \mathrm{~h}, 30^{\circ} \mathrm{C}$ & ND & 0.32 & [50] \\
\hline Sugarcane bagasse & C. guilliermondii ATCC 201935 & $72 \mathrm{~h}, 30^{\circ} \mathrm{C}$ & 17.0 & 0.42 & [51] \\
\hline Sugarcane bagasse & C. magnoliae TISTR 5663 & $288 \mathrm{~h}, 30^{\circ} \mathrm{C}$ & 4.8 & 0.30 & [52] \\
\hline Sugarcane bagasse & C. tropicalis Y-27290 & $40 \mathrm{~h}, 30^{\circ} \mathrm{C}$ & 34.5 & 0.86 & [53] \\
\hline Sugarcane bagasse & C. tropicalis MTCC 184 & $36 \mathrm{~h}, 30^{\circ} \mathrm{C}$ & 10.2 & 0.56 & [54] \\
\hline Sugarcane bagasse & C. tropicalis JA2 & $39 \mathrm{~h}, 30^{\circ} \mathrm{C}$ & 109.5 & 0.86 & [55] \\
\hline Sugarcane bagasse & C. tropicalis UFMGBX12 & $96 \mathrm{~h}, 30^{\circ} \mathrm{C}$ & 12.0 & 0.61 & [56] \\
\hline Sugarcane straw & C. guilliermondii ATCC 201935 & $48 \mathrm{~h}, 30^{\circ} \mathrm{C}$ & 8.7 & 0.67 & [57] \\
\hline Water hyacinth leaves & C. tropicalis MTCC 230 & $48 \mathrm{~h}, 30^{\circ} \mathrm{C}$ & 9.9 & 0.47 & {$[34]$} \\
\hline Wheat bran & C. boidinii NCAIM Y.01308 & $24 \mathrm{~h}, 30^{\circ} \mathrm{C}$ & 14.2 & 0.72 & [61] \\
\hline
\end{tabular}

${ }^{1}$ The listed xylitol levels and yields were provided in the cited references.

\section{Xylitol Production by Candida Species from Grasses}

The ability of Candida species to produce xylitol from hydrolysates of North American prairies grasses has been examined [62,63]. As shown in Table 2, the type of Candida species used to ferment the grass was important to the fermentation parameters xylitol level and yield. In the initial study, an acid hydrolysate of the prairie grass big bluestem (Andropogon gerardii) was investigated for its ability to support xylitol production by Candida species [62]. The untreated big bluestem contained 34\% cellulose, $20 \%$ hemicellulose and $20.4 \%$ lignin [64]. It was found that $C$. tropicalis ATCC 750 produced the highest xylitol level after $120 \mathrm{~h}$ on the $1 \%$ sulfuric acid-treated $\left(121^{\circ} \mathrm{C}, 20 \mathrm{~min}\right)$ hydrolysate of big bluestem buffered at pH 5.0 compared to the other Candida species tested (Table 2) [62].

Table 2. Xylitol production by Candida species strains grown on $\mathrm{pH}$ 5.0-buffered grass hydrolysates.

\begin{tabular}{|c|c|c|c|c|c|}
\hline Grass & $\begin{array}{c}\text { Candida Species/ } \\
\text { Strain }\end{array}$ & $\begin{array}{l}\text { Growth } \\
\text { Conditions }\end{array}$ & $\begin{array}{c}\text { Xylitol } \\
\text { Level (g/L) }^{1}\end{array}$ & Yield $(g / g)^{1}$ & Reference \\
\hline Big bluestem & C. guilliermondii ATCC 20216 & $120 \mathrm{~h}, 30^{\circ} \mathrm{C}$ & 15.6 & 0.46 & [62] \\
\hline Big bluestem & C. guilliermondii ATCC 201935 & $120 \mathrm{~h}, 30^{\circ} \mathrm{C}$ & 14.6 & 0.38 & [62] \\
\hline Big bluestem & C. mogii ATCC 18365 & $120 \mathrm{~h}, 30^{\circ} \mathrm{C}$ & 13.8 & 0.42 & [62] \\
\hline Big bluestem & C. tropicalis ATCC 750 & $120 \mathrm{~h}, 30^{\circ} \mathrm{C}$ & 16.5 & 0.43 & [62] \\
\hline Big bluestem & C. tropicalis ATCC 20215 & $120 \mathrm{~h}, 30^{\circ} \mathrm{C}$ & 11.9 & 0.31 & [62] \\
\hline Prairie cordgrass & C. mogii ATCC 18365 & $120 \mathrm{~h}, 30^{\circ} \mathrm{C}$ & 12.8 & 0.75 & [63] \\
\hline Prairie cordgrass & C. guilliermondii ATCC 20216 & $120 \mathrm{~h}, 30^{\circ} \mathrm{C}$ & 13.7 & 0.81 & [63] \\
\hline Prairie cordgrass & C. guilliermondii ATCC 201935 & $120 \mathrm{~h}, 30^{\circ} \mathrm{C}$ & 10.9 & 0.76 & [63] \\
\hline
\end{tabular}

\footnotetext{
${ }^{1}$ The listed xylitol levels and yields were stated in the cited references.
} 
The highest xylitol yield was produced by C. guilliermondii ATCC 20216 after growth on the big bluestem hydrolysate buffered at $\mathrm{pH} 5.0$ for $120 \mathrm{~h}$ at $30^{\circ} \mathrm{C}$ relative to xylitol synthesis by the four other Candida strains explored (Table 2). Another study investigated xylitol production by Candida species grown on hydrolysates of the prairie grass prairie cordgrass (Spartina pectinata) [63]. The untreated prairie cordgrass contained 33.5\% cellulose, $13.5 \%$ hemicellulose and 21\% lignin [63]. It can be witnessed in Table 2 that C. guilliermondii ATCC 20216 produced a higher concentration of xylitol as well as a higher yield on the prairie cordgrass hydrolysate buffered at pH 5.0 than the other strains assayed in the study. Xylitol production by the three Candida species grown on the enzyme-treated prairie cordgrass hydrolysate $\left(121^{\circ} \mathrm{C}, 30 \mathrm{~min}\right)$ buffered at $\mathrm{pH} 5.0$ was lower than the xylitol production by the same three species grown on big bluestem after $120 \mathrm{~h}$ at $30{ }^{\circ} \mathrm{C}$ (Table 2) [63]. It should be noted that the effect of the buffering $\mathrm{pH}$ of the prairie cordgrass hydrolysate was studied relative to xylitol production as well as xylitol yield [63]. In this work, Candida mogii ATCC 18365, C. guilliermondii ATCC 20216 and C. guilliermondii ATCC 201935 produced the highest xylitol levels after $120 \mathrm{~h}$ at $30{ }^{\circ} \mathrm{C}$ when the prairie cordgrass hydrolysate was buffered to $\mathrm{pH} 5.5$ [63]. The highest yield was produced by C. mogii ATCC 18364 after growth for $120 \mathrm{~h}$ at $30^{\circ} \mathrm{C}$ on the $\mathrm{pH}$ 5.5-buffered cordgrass hydrolysate-containing medium, but it can be observed that the xylitol yields produced by C. guilliermondii ATCC 20216 and ATCC 201935 on the $\mathrm{pH}$ 5.5-buffered hydrolysate-containing medium were only slightly lower [62]. In contrast, if the Candida strains were grown on the cordgrass hydrolysate-containing medium buffered at $\mathrm{pH} 4.5$ or 6.0 , the lowest xylitol yields were produced after $120 \mathrm{~h}$ at $30{ }^{\circ} \mathrm{C}$ [62]. The xylitol yield produced by C. mogii ATCC 18364 (0.89 g xylitol/[g xylose consumed]), C. guilliermondii ATCC 20216 (0.87 g xylitol/[g xylose consumed]) or ATCC 201935 (0.84 g xylitol/[g xylose consumed]) grown on medium containing the cordgrass hydrolysate buffered at $\mathrm{pH} 5.5$ was much higher than the xylitol yields observed when the strains were grown in acid-treated big bluestem hydrolysates buffered at $\mathrm{pH} 5.0$ [62,63]. In conclusion, prairie cordgrass hydrolysates appeared to be superior to big bluestem hydrolysates in supporting xylitol production by Candida species. The low xylitol yields observed after the growth of the Candida species on the big bluestem hydrolysates may be due to the toxic products generated by the treatment of the big bluestem with dilute sulfuric acid [62]. The acid hydrolysis of biomass using high temperature and pressure usually results in the formation of furfurals from pentoses that tend to be inhibitory in general to yeast bioconversion processes. In addition, the effect of buffering the big bluestem hydrolysate at a $\mathrm{pH}$ other than 5.0 was not examined, so it is not clear if higher xylitol yields could have been obtained if the big bluestem hydrolysate was buffered at pH 5.5 [62].

\section{Conclusions}

A number of investigations have examined the ability of Candida species to utilize hydrolysates of agricultural residues and grasses to support xylitol synthesis. In general, it can be concluded that hydrolysates of agricultural residues supported higher levels of xylitol production by Candida species than did grass hydrolysates. More specifically, a hydrolysate of sugarcane bagasse supported the highest level of xylitol production by Candida species (Table 1). It did appear that the corncob hydrolysates also supported substantial xylitol production and high xylitol yields by a variety of $C$. tropicalis strains. The previous studies demonstrate the critical nature of biomass pretreatment techniques in providing a high xylose concentration to support yeast xylitol production as well as the optimization of the yeast fermentation condition to further enhance xylitol synthesis. In addition, it should be noted that fewer studies have explored the use of grass hydrolysates to support xylitol synthesis by Candida species than studies focusing on hydrolysates of agricultural residues. This indicates a need for further research to be conducted on the use of hydrolysates from other grass species by Candida species for xylitol production. It may be possible to identify a species of grass whose hydrolysate may contain a higher xylose content that would promote increased xylitol production by species of Candida. It 
should also be mentioned that the obstacles encountered in yeast xylitol production from lignocellulosic biomass are quite similar to those found when producing bioethanol from such biomass.

Funding: This research was funded by the Welch Foundation Grant T-0014 and the South Dakota Agricultural Experiment Station Grant No. SD00067-H.

Conflicts of Interest: The author declares no conflict of interest.

\section{References}

1. Gränstrom, T.B.; Izumori, K.; Leisola, M. A rare sugar xylitol. Part II: Biotechnological production and future applications of xylitol. Appl. Microbiol. Biotechnol. 2007, 74, 273-276. [CrossRef] [PubMed]

2. Edomi, A. Xylitol: Its properties and food applications. Food Technol. 1978, 32, 20-32.

3. Petch, D.; Butler, M. The effect of alternative carbohydrates on the growth and antibody production of a murine hybridoma. Appl. Biochem. Biotechnol. 1996, 59, 93-104. [CrossRef] [PubMed]

4. Uhari, M.; Kontiokari, T.; Niemela, M. A novel use of xylitol sugar in preventing acute otitis media. Pediatrics 1998, 102, 879-884. [CrossRef] [PubMed]

5. Subroto, E.; Hayati, F. Chemical and biotechnological methods for the production of xylitol: A review. IJETER 2020, 8 , 2508-2512. [CrossRef]

6. Xiang, S.; Ye, K.; Li, M.; Ying, J.; Wang, H.; Han, J.; Shi, L.; Xiao, J.; Shen, Y.; Feng, X.; et al. Xylitol enhances synthesis of propionate in the colon via cross-feeding of gut microbiota. Microbiome 2021, 9, 62. [CrossRef]

7. Xu, Y.; Chi, P.; Bilal, M.; Cheng, H. Biosynthetic strategies to produce xylitol: An economical venture. Appl. Microbiol. Biotechnol. 2019, 103, 5143-5160. [CrossRef]

8. Silva, S.S.; Matos, Z.R.; Carvalho, W. Effects of sulfuric acid loading and resident time on the composition of sugarcane bagasse hydrolysate and its use as a source of xylose for xylitol bioproduction. Biotechnol. Prog. 2005, 21, 1449-1452. [CrossRef]

9. Saha, B.C.; Kennedy, G.J. Production of xylitol from mixed sugars of xylose and arabinose without co-producing arabitol. Biocatal. Agric. Biotechnol. 2020, 29, 101786. [CrossRef]

10. Zhang, Y.-H.P. Reviving the carbohydrate economy via multiproduct lignocellulose biorefineries. J. Ind. Microbiol. Biotechnol. 2008, 35, 367-375. [CrossRef]

11. Mulkey, V.R.; Owens, V.N.; Lee, D.K. Management of warm-season grass mixtures for biomass production in South Dakota USA. Bioresour. Technol. 2008, 99, 609-617. [CrossRef]

12. West, T.P.; Peterson, J.L. Production of the polysaccharide curdlan by an Agrobacterium strain grown on a plant biomass hydrolysate. Can. J. Microbiol. 2014, 60, 53-56. [CrossRef] [PubMed]

13. West, T.P. Effect of nitrogen source concentration on curdlan production by Agrobacterium sp. ATCC 31749 grown on prairie cordgrass hydrolysates. Prep. Biochem. Biotechnol. 2016, 46, 85-90. [CrossRef]

14. West, T.P. Fungal production of the polysaccharide pullulan from a plant hydrolysate. Z. Naturforsch. C 2017, 72, 491-496. [CrossRef]

15. Kennedy, D.E., II; West, T.P. Effect of yeast extract addition to a mineral salts medium containing hydrolyzed plant xylan on fungal pullulan production. Z. Naturforsch. C 2018, 73, 319-323. [CrossRef] [PubMed]

16. West, T.P. Production of the polysaccharide curdlan by Agrobacterium species on processing coproducts and plant lignocellulosic hydrolysates. Fermentation 2020, 6, 16. [CrossRef]

17. Onishi, H.; Suzuki, T. Microbial production of xylitol from glucose. Appl. Microbiol. 1969, 18, 1031-1035. [CrossRef]

18. Barbosa, M.F.S.; de Medeiros, M.B.; de Mancilha, I.M.; Schneider, H.; Lee, H. Screening of yeasts for production of xylitol from D-xylose and some factors which affect xylitol yield in Candida guilliermondii. J. Ind. Microbiol. 1988, 3, 241-251. [CrossRef]

19. Mayerhoff, Z.D.V.L.; Roberto, I.C.; Silva, S.S. Xylitol production from rice straw hemicellulose using different yeast strains. Biotechnol. Lett. 1997, 19, 407-409. [CrossRef]

20. Guo, C.; Zhao, C.; He, P.; Shen, A.; Jiang, N. Screening and characterization of yeasts for xylitol production. J. Appl. Microbiol. 2006, 101, 1096-1104. [CrossRef]

21. Kwaka, S.; Job, J.H.; Yuna, E.J.; Jina, Y.-S.; Seo, J.-H. Production of biofuels and chemicals from xylose using native and engineered yeast strains. Biotechnol. Adv. 2019,37, 219-283. [CrossRef] [PubMed]

22. Cardoso, B.S.; Forte, M.B.S. Purification of biotechnological xylitol from Candida tropicalis fermentation using activated carbon in fixed-bed adsorption columns with continuous feed. Food Bioprod. Process. 2021, 126, 73-80. [CrossRef]

23. Neuhauser, W.; Haltrich, D.; Kulbe, K.D.; Nideetzky, B. NAD(P)H-dependent aldose reductase from the xylose-assimilating yeast Candida tenuis: Isolation, characterization and biochemical properties of the enzyme. Biochem. J. 1997, 326, 683-692. [CrossRef] [PubMed]

24. Handumrongkul, C.; Ma, D.-P.; Silva, J.L. Cloning and expression of Candida guilliermondii xylose reductase gene (xyl1) in Pichia pastoris. Appl. Microbiol. Biotechnol. 1998, 49, 399-404. [CrossRef]

25. Sene, L.; Felipe, M.G.A.; Silva, S.S.; Vitolo, M. Preliminary kinetic characterization of xylose reductase and xylitol dehydrogenase extracted from Candida guilliermondii FTI 20037 cultivated in sugarcane bagasse hydrolysate for xylitol production. Appl. Biochem. Biotechnol. 2001, 91-93, 671-680. [CrossRef] 
26. Kavanagh, K.L.; Klimacek, M.; Nidetzky, B.; Wilson, D.K. The Structure of apo and holo forms of xylose reductase, a dimeric aldo-keto reductase from Candida tenuis. Biochemistry 2002, 41, 8785-9795. [CrossRef]

27. Mayr, P.; Bruggler, K.; Kulbe, K.D.; Nidetzky, B. D-Xylose metabolism by Candida intermedia: Isolation and characterisation of two forms of aldose reductase with different coenzyme specificities. J. Chromatogr. B Biomed. Sci. Appl. 2000, 737, 195-202. [CrossRef]

28. Lee, J.-K.; Koo, B.S.; Kim, S.-Y. Cloning and characterization of the $x y l 1$ gene, encoding an NADH-preferring xylose reductase from Candida parapsilosis, and its functional expression in Candida tropicalis. Appl. Environ. Microbiol. 2003, 69, 6179-6188. [CrossRef]

29. Kratzer, R.; Wilson, D.K.; Nidetzky, B. Catalytic mechanism and substrate selectivity of aldo-keto reductases: Insights from structure-function studies of Candida tenuis xylose reductase. Life 2006, 58, 499-507. [CrossRef]

30. Chen, L.-C.; Huang, S.-C.; Chuankhayan, P.; Chen, C.-D.; Huang, Y.-H.; Jeyakanthan, J.; Pang, H.-F.; Men, L.-C.; Chen, Y.-C.; Wang, Y.-K.; et al. Purification, crystallization and preliminary X-ray crystallographic analysis of xylose reductase from Candida tropicalis. Acta Crystallogr. Sect. F Struct. Biol. Cryst. Commun. 2009, F65, 419-421. [CrossRef] [PubMed]

31. Rafiqul, I.S.M.; Sakinah, A.M.M. Biochemical properties of xylose reductase prepared from adapted strain of Candida tropicalis. Appl. Biochem. Biotechnol. 2015, 175, 387-399. [CrossRef]

32. Kim, S.; Lee, J.; Sung, B.H. Isolation and characterization of the stress-tolerant Candida tropicalis YHJ1 and evaluation of its xylose reductase for xylitol production from acid pre-treatment wastewater. Front Bioeng. Biotechnol. 2019, 7, 138. [CrossRef]

33. Leonel, L.V.; Sene, L.; da Cunha, M.A.A.; Dalanhol, K.C.F.; Felipe, M.G.A. Valorization of apple pomace using bio-based technology for the production of xylitol and 2G ethanol. Bioproc. Biosyst. Eng. 2020, 43, 2153-2163. [CrossRef] [PubMed]

34. Shankar, K.; Kulkarnia, N.S.; Sajjanshettya, R.; Jayalakshmib, S.K.; Sreeramulua, K. Co-production of xylitol and ethanol by the fermentation of the lignocellulosic hydrolysates of banana and water hyacinth leaves by individual yeast strains. Ind. Crop. Prod. 2020, 155, 112809. [CrossRef]

35. Eryasar-Orer, K.; Karasu-Yalcin, S. Optimization of activated charcoal detoxification and concentration of chestnut shell hydrolysate for xylitol production. Biotechnol. Lett. 2021, 43, 1195-1209. [CrossRef] [PubMed]

36. Santana, N.B.; Dias, J.C.T.; Rezende, R.P.; Franco, M.; Oliveira, L.K.S.; Souza, L.O. Production of xylitol and bio-detoxification of cocoa pod husk hemicellulose hydrolysate by Candida boidinii XM02G. PLoS ONE 2018, 13, e0195206. [CrossRef] [PubMed]

37. Irmak, S.; Canisag, H.; Vokoun, C.; Meryemoglu, B. Xylitol production from lignocellulosics: Are corn biomass residues good candidates? Biocatal. Agric. Biotechnol. 2017, 11, 220-223. [CrossRef]

38. Ping, Y.; Ling, H.-Z.; Song, G.; Ge, J.-P. Xylitol production from non-detoxified corncob hemicellulose acid hydrolysate by Candida tropicalis. Biochem. Eng. J. 2013, 75, 86-91. [CrossRef]

39. Guo, X.; Zhang, R.; Li, Z.; Dai, D.; Li, C.; Zhou, X. A novel pathway construction in Candida tropicalis for direct xylitol conversion from corncob xylan. Bioresour. Technol. 2013, 128, 547-552. [CrossRef] [PubMed]

40. Kumar, V.; Sandhu, P.P.; Ahluwalia, V.; Mishra, B.B.; Yada, S.K. Efficient detoxification of corn cob hydrolysate with ion-exchange resins for enhanced xylitol production by Candida tropicalis MTCC 6192. Bioresour. Technol. 2018, 251, 416-419. [CrossRef]

41. Kumar, V.; Sandhu, P.P.; Ahluwalia, V.; Mishra, B.B.; Yada, S.K. Improved upstream processing for detoxification and recovery xylitol produced from corncob. Bioresour. Technol. 2019, 291, 121931. [CrossRef]

42. Li, Z.; Guo, X.; Feng, X.; Li, C. An environment friendly and efficient process for xylitol bioconversion from enzymatic corncob hydrolysate by adapted Candida tropicalis. Chem. Eng. J. 2015, 263, 249-256. [CrossRef]

43. Yewale, T.; Panchwagh, S.; Rajagopalan, S.; Dhamole, P.B.; Jain, R. Enhanced xylitol production using immobilized Candida tropicalis with non-detoxified corn cob hemicellulosic hydrolysate. 3 Biotech 2016, 6, 75. [CrossRef]

44. Sapc1, B.; Akpinar, O.; Bolukbasi, U.; Yilmaz, L. Evaluation of cotton stalk hydrolysate for xylitol production. Prep. Biochem. Biotechnol. 2016, 46, 474-482. [CrossRef]

45. López-Linares, J.C.; Ruiz, E.; Romero, I.; Castro, E.; Manzanares, P. Xylitol production from exhausted olive pomace by Candida boidinii. Appl. Sci. 2020, 10, 6966. [CrossRef]

46. Mateo, S.; Puentes, J.G.; Moya, A.J.; Sánchez, S. Ethanol and xylitol production by fermentation of acid hydrolysate from olive pruning with Candida tropicalis NBRC 0618. Bioresour. Technol. 2015, 190, 1-6. [CrossRef] [PubMed]

47. López-Linaresa, J.C.; Romeroa, I.; Caraa, C.; Castroa, E.; Solange, I. Mussatto SI. Xylitol production by Debaryomyces hansenii and Candida guilliermondii from rapeseed straw hemicellulosic hydrolysate. Bioresour. Technol. 2018, 247, 736-743. [CrossRef] [PubMed]

48. Singh, S.; Dalveer, D.; Yadav, S.K.; Krishania, M. Process scale-up of an efficient acid-catalyzed steam pretreatment of rice straw for xylitol production by C. tropicalis MTCC 6192. Bioresour. Technol. 2021, 320, 124422.

49. Zahed, O.; Jouzani, G.S.; Abbasalizadeh, S.; Khodaiyan, F.; Tabatabaei, M. Continuous co-production of ethanol and xylitol from rice straw hydrolysate in a membrane bioreactor. Folia Microbiol. 2016, 61, 179-189. [CrossRef]

50. Xavier, F.D.; Bezerra, G.S.; Santos, S.F.M.; Oliveira, L.S.C.; Silva, F.L.H.; Silva, A.J.O.; Conceição, M.M. Evaluation of the simultaneous production of xylitol and ethanol from sisal fiber. Biomolecules 2018, 8, 2.

51. Santos, J.C.; Carvalho, W.; Silva, S.S.; Converti, A. Xylitol production from sugarcane bagasse hydrolyzate in fluidized bed reactor. Effect of air flowrate. Biotechnol. Prog. 2003, 19, 1210-1215. [CrossRef] [PubMed]

52. Wannawilai, S.; Sirisansaneeyakul, S. Economical production of xylitol from Candida magnolia TISTR 5663 using sugarcane bagasse hydrolysate. Kasetsart J. Nat. Sci. 2015, 49, 583-596.

53. Raj, K.; Krishnan, C. Improved co-production of ethanol and xylitol from low-temperature aqueous ammonia pretreated sugarcane bagasse using two-stage high solids enzymatic hydrolysis and Candida tropicalis. Renew. Energy 2020, 153, 392-403. [CrossRef] 
54. Tizazu, B.Z.; Roy, K.; Moholkar, V.S. Mechanistic investigations in ultrasound-assisted xylitol fermentation. Ultrason. Sonochem. 2018, 48, 321-328. [CrossRef]

55. Morais, W.G., Jr.; Pacheco, T.F.; Trichez, D.; Almeida, J.R.M.; Gonçalves, S.B. Xylitol production on sugarcane biomass hydrolysate by newly identified Candida tropicalis JA2 strain. Yeast 2019, 36, 349-361. [CrossRef] [PubMed]

56. Antunes, F.A.F.; Thome, L.C.; Santos, J.C.; Ingle, A.P.; Costa, C.B.; Anjo, V.D.; Bell, M.J.V.; Rosa, C.A.; Da Silva, S.S. Multi-scale study of the integrated use of the carbohydrate fractions of sugarcane bagasse for ethanol and xylitol production. Renew. Energy 2021, 163, 1343-1355. [CrossRef]

57. Hernández-Pérez, A.F.; de Arruda, P.V.; de Almeida Felipe, M.G. Sugarcane straw as a feedstock for xylitol production by Candida guilliermondii FTI 20037. Braz. J. Microbiol. 2016, 47, 489-496. [CrossRef] [PubMed]

58. Santos, J.C.; Pinto, I.R.G.; Carvalho, W.; Mancilha, I.M.; Felipe, M.G.A.; Silva, S.S. Sugarcane bagasse as raw material and immobilization support for xylitol production. Appl. Biochem. Biotechnol. 2005, 121-124, 673-683. [CrossRef]

59. Silva, S.S.; Solange, I.; Mussatto, S.I.; Santos, J.C.; Santos, D.T.; Polizel, J. Cell immobilization and xylitol production using sugarcane bagasse as raw material. Appl. Biochem. Biotechnol. 2007, 141, 215-227. [CrossRef]

60. Dorantes-Landa, D.N.; Cocotle-Ronzón, Y.; Morales-Cabreraa, M.A.; Hernández-Martíneza, E. Modeling of the xylitol production from sugarcane bagasse by immobilized cells. J. Chem. Technol. Biotechnol. 2020, 95, 1936-1945. [CrossRef]

61. Bedó, S.; Fehér, A.; Khunnonkwao, P.; Jantama, K.; Fehér, C. Optimized bioconversion of xylose derived from pre-treated crop residues into xylitol by using Candida boidinii. Agronomy 2021, 11, 79. [CrossRef]

62. West, T.P. Xylitol production by Candida species grown on a grass hydrolysate. World J. Microbiol. Biotechnol. 2009, 25, 913-916. [CrossRef]

63. Rudrangi, S.R.R.; West, T.P. Effect of $\mathrm{pH}$ on xylitol production by Candida species from a prairie cordgrass hydrolysate. Z. Naturforsch. C 2020, 75, 489-493. [CrossRef] [PubMed]

64. Dien, B.S.; Mitchell, R.B.; Bowman, R.J.; Jin, V.L.; Quarterman, J.; Schmer, M.R.; Singh, V.; Sliminger, P.J. Bioconversion of pelletized big bluestem, switchgrass and low-diversity grass mixtures into sugars and bioethanol. Front. Energy Res. 2018, 6, 129. [CrossRef] 